\title{
Tracking the changes in virus taxonomy
}

\author{
M. J. Adams • R. C. Hendrickson • D. M. Dempsey • \\ E. J. Lefkowitz
}

Received: 5 January 2015/Accepted: 14 February 2015/Published online: 25 February 2015

(C) Springer-Verlag Wien 2015

\begin{abstract}
A database and website (http://www.ictvonline. org/taxonomyReleases.asp) have been established where the history of changes in virus taxonomy from 1971 to the present day can easily be traced. Each change is linked to a source document confirming the change or, for most changes since 2002, to the taxonomic proposal approved by the International Committee on Taxonomy of Viruses (ICTV).
\end{abstract}

\section{Introduction}

The attempt to create a universal taxonomic scheme for all viruses began in earnest at the IXth Congress of the International Association of Microbiological Societies (IAMS), held in Moscow in 1966. Meetings at the congress formally established what was termed the International Committee on Nomenclature of Viruses (ICNV). The Committee was so constituted that, wherever practicable, each country was represented by at least one member nominated by the microbiological society of that country. The first Executive Committee (EC) was also appointed

M. J. Adams $(\square)$

24 Woodland Way, Stevenage, Herts SG2 8BT, UK

e-mail: mike.adams.ictv@gmail.com

R. C. Hendrickson - D. M. Dempsey · E. J. Lefkowitz Department of Microbiology, University of Alabama at Birmingham (UAB), BBRB 276, 845 19th ST South, Birmingham, AL 35294-2170, USA

e-mail: curtish@uab.edu

D. M. Dempsey

e-mail: ddempsey@uab.edu

E. J. Lefkowitz

e-mail: elliotl@uab.edu with Professor Peter Wildy as its President. Members of the EC were appointed to chair subcommittees to develop taxonomy for the viruses of bacteriophage, invertebrates, plants and vertebrates, all of which would need the approval of the EC and of the entire ICNV.

While there have been some changes, this pattern of operation has largely continued to the present day. The ICNV was renamed the International Committee on Taxonomy of Viruses (ICTV) in 1974 and is today a committee of the Virology Division of the International Union of Microbiological Societies (IUMS).

Virus taxonomy differs from other types of biological classification because the ICTV not only regulates a Code of Nomenclature but also considers and approves the creation of virus taxa (currently orders, families, subfamilies, genera and species). Priority of publication is not the determining factor. The names of all recognized taxa are nowadays written in italics with an initial capital letter. All changes in taxonomy must first be approved by the EC and then by the entire voting membership of the ICTV. In the early years, the final vote was taken at an ICTV plenary session at an International Congress of Virology. These congresses have generally been held every three years, and the original intention was then to publish a report setting out the revised taxonomy following the Congress. With the passage of time, the ICTV reports developed into large reference works, requiring major efforts in editing and publication, and it has become impractical to publish them every three years. In addition, the explosion in virus discovery has meant that taxonomic changes need to be made more frequently. The current pattern is for annual changes, with the final ratification vote being conducted by e-mail.

The first formal report on virus classification was published in 1971 [25]. This report, which laid the foundation for viral taxonomy, covers the period from the formation of 
Table 1 Time points and references for changes in virus taxonomy
* Minutes of these Plenary Sessions are available online: https://talk.ictvonline.org/files/ ictv_documents/m/plenary_ minutes/default.aspx

${ }^{\dagger}$ The ICTV $9^{\text {th }}$ Report was published in 2011 but its taxonomy is unchanged from 2009

\begin{tabular}{|c|c|c|}
\hline Date & Event & Reference \\
\hline 1971 & ICNV $1^{\text {st }}$ Report & {$[25]$} \\
\hline 1974 & Postal vote April-May 1974 & {$[8]$} \\
\hline 1975 & Plenary session vote September 1975 in Madrid & See footnote* \\
\hline 1976 & ICTV $2^{\text {nd }}$ Report & {$[7]$} \\
\hline 1978 & Plenary session vote August 1978 in The Hague & See footnote* \\
\hline 1979 & ICTV $3^{\text {rd }}$ Report & {$[11]$} \\
\hline 1981 & Plenary session vote August 1981 in Strasbourg & See footnote* \\
\hline 1982 & ICTV $4^{\text {th }}$ Report & {$[12]$} \\
\hline 1984 & Plenary session vote September 1984 in Sendai & See footnote* \\
\hline 1987 & Plenary session vote August 1987 in Edmonton & See footnote* \\
\hline 1990 & Plenary session vote August 1990 in Berlin & See footnote* \\
\hline 1991 & ICTV $5^{\text {th }}$ Report & {$[9]$} \\
\hline 1993 & Plenary session vote August 1993 in Glasgow & {$[18]$} \\
\hline 1995 & ICTV $6^{\text {th }}$ Report & {$[17]$} \\
\hline 1996 & Plenary session vote August 1996 in Jerusalem & {$[19]$} \\
\hline 1997 & Postal vote autumn 1997 & {$[20]$} \\
\hline 1998 & Postal vote autumn 1998 & {$[21,23]$} \\
\hline 1999 & ICTV $7^{\text {th }}$ Report & {$[24]$} \\
\hline 1999 & Plenary session vote August 1999 in Sydney & {$[22]$} \\
\hline 2002 & Postal vote spring 2002 & {$[13,14]$} \\
\hline 2002 & Plenary session vote July 2002 in Paris & {$[15]$} \\
\hline 2004 & Postal vote 2004 & {$[16]$} \\
\hline 2005 & ICTV $8^{\text {th }}$ Report & [6] \\
\hline 2008 & Postal vote March 2008 & {$[5]$} \\
\hline 2009 & E-mail vote July 2009 & {$[4]$} \\
\hline $2011^{\dagger}$ & ICTV $9^{\text {th }}$ Report & {$[10]$} \\
\hline 2011 & E-mail vote February 2012 & {$[1]$} \\
\hline 2012 & E-mail vote February 2013 & {$[3]$} \\
\hline 2013 & E-mail vote March 2014 & {$[2]$} \\
\hline
\end{tabular}

the ICNV in 1966 until 1970. Since then, there have been 27 occasions on which official taxonomy has changed. These changes may be traced by consulting the published reports of the ICTV and various articles (most of them in Archives of Virology) that have summarised the changes agreed by voting at virology congresses or by postal or e-mail ballots (Table 1). To make this information readily accessible, we have now developed a database and website where the entire history of taxonomic changes from 1971 to the present day can easily be traced. Each change is linked to a source document confirming the change or, for most changes since 2002, to the taxonomic proposal approved by the ICTV.

\section{Preliminary considerations}

Because the taxonomic categories recognised by the ICTV have changed over the years, some approximations or conventions have been adopted to ensure that all changes can be tracked.

The early published reports consisted of brief summaries of the genera officially recognized by the ICTV (and a small number of families), with lists of viruses that were considered 'members', 'probable members' and 'possible members' of these genera. One of the member viruses was identified as the 'type member' or 'type species'. Plant viruses were presented in 'groups' until more data were available to determine whether these groups corresponded to genera or families. All such groups had disappeared by 1993, most of them being recognised and renamed as genera. Before about 1996, there were not usually specific proposals and ballots of ICTV members to establish new member viruses (or species) and the lists were revised (sometimes extensively) by the relevant study groups when each ICTV Report was published. Until this stage in the history of the ICTV, there had been no agreement on the need for, or definition of, virus species, but species were 


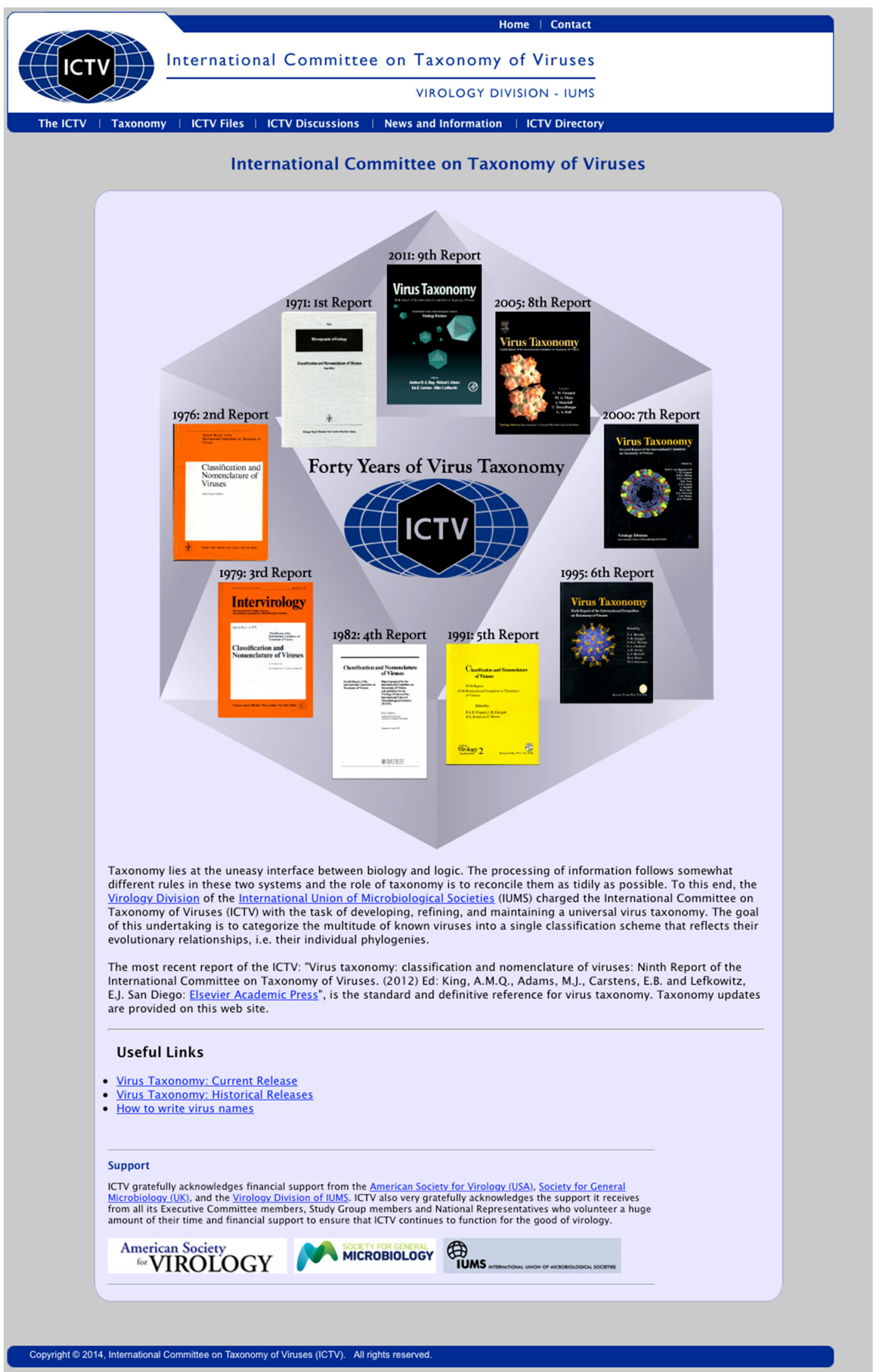

Fig. 1 Screen shot of the ICTV web site home page, http://www.ictvonline.org 


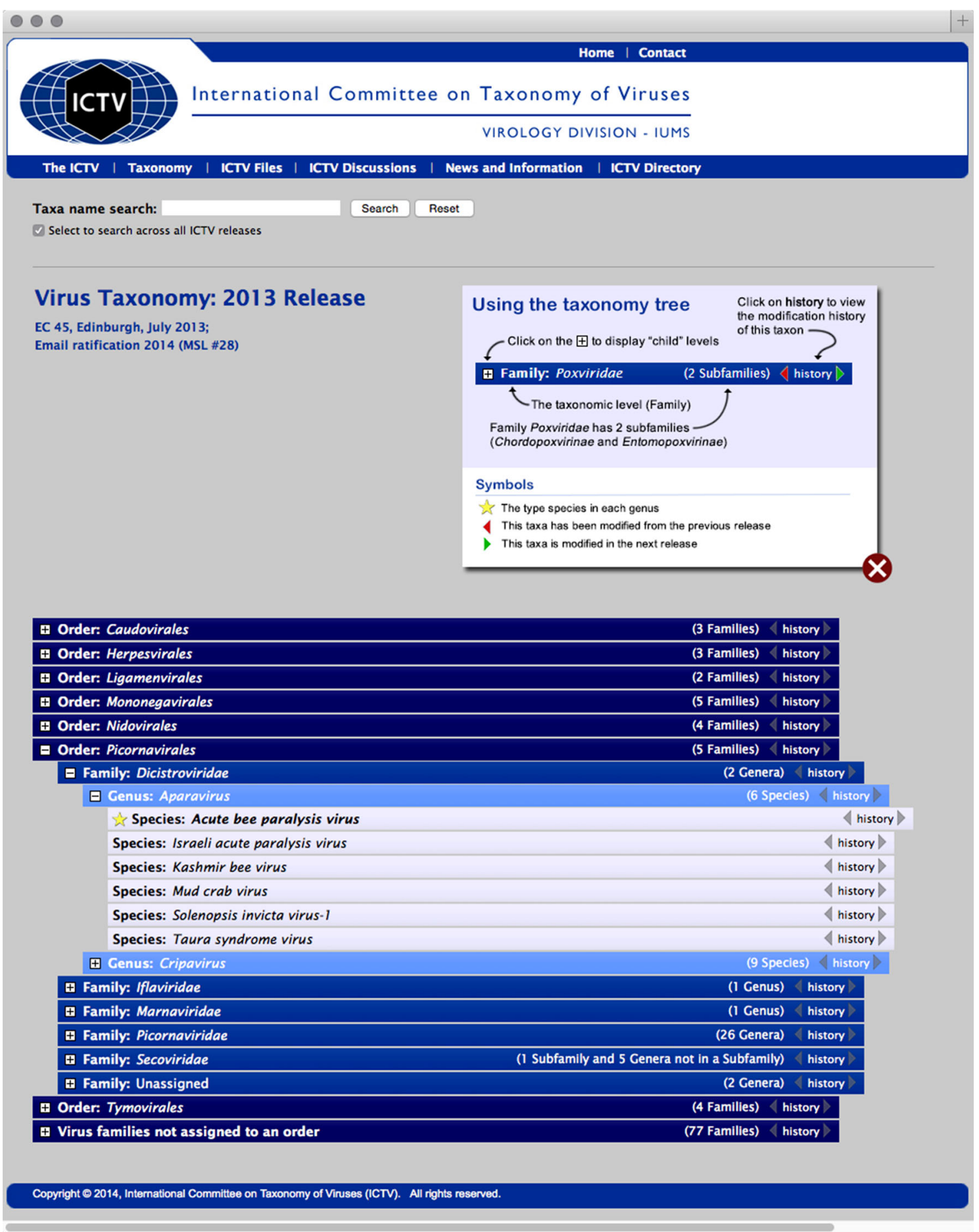

Fig. 2 Screen shot of the ICTV web site current taxonomy release, http://www.ictvonline.org/virusTaxonomy.asp

systematically introduced for the Seventh Report [24]. In many cases, these species lists corresponded to the viruses listed earlier as genus members, but in some genera closely related viruses were classified into a single species. Possible or probable members of genera and families were then listed as 'tentative species'.
For the purpose of the database, the viruses listed as genus 'members' from 1971-1995 are treated as species. The 'groups' are usually treated as genera. No attempt has been made to list 'possible members', 'probable members' or 'tentative species'. Where changes to taxonomy occurred, links are provided to proposal documents or other 


\section{Taxonomy Releases}

The following list represents all ICTV taxonomy releases to date. To view the corresponding taxonomy tree, click on the hyper-linked year next to the release.

\begin{tabular}{|c|c|c|c|c|c|c|}
\hline Year & Release Info & Orders & Families & Subfam. & Genera & Species \\
\hline$\underline{2013}$ & EC 45, Edinburgh, July 2013; Email ratification 2014 (MSL \#28) & 7 & 103 & 22 & 455 & 2827 \\
\hline$\underline{2012}$ & EC 44, Leuven, July 2012; Email ratification 2013 (MSL \#27) & 7 & 96 & 22 & 420 & 2617 \\
\hline$\underline{2011}$ & $\begin{array}{l}\text { EC 42: Paris, June, 2010; EC43: Sapporo, September 2011; } \\
\text { Email ratification } 2012 \text { (MSL \#26) }\end{array}$ & 6 & 94 & 22 & 395 & 2480 \\
\hline$\underline{2009}$ & $\begin{array}{l}\text { ICTV 9th Report; EC41: Leiden, June 2009; Email ratification } \\
2009 \text { (MSL \#25) }\end{array}$ & 6 & 87 & 19 & 349 & 2285 \\
\hline$\underline{2008}$ & $\begin{array}{l}\text { EC 39: Kingston, June, 2007; EC 40: Istanbul, August 2008; } \\
\text { Email ratification } 2008 \text { (MSL \#24) }\end{array}$ & 5 & 82 & 11 & 307 & 2078 \\
\hline$\underline{2005}$ & ICTV 8th Report (MSL \#23) & 3 & 73 & 11 & 289 & 1898 \\
\hline$\underline{2004}$ & Postal vote 2004 (MSL \#22) & 3 & 73 & 11 & 290 & 1832 \\
\hline$\underline{2002}$ & Plenary session vote 30 July 2002 in Paris (MSL \#21) & 3 & 70 & 11 & 251 & 1619 \\
\hline$\underline{2002}$ & Postal vote spring 2002 (MSL \#20) & 3 & 70 & 9 & 247 & 1602 \\
\hline$\underline{1999}$ & Plenary session vote August 1999 in Sydney (MSL \#19) & 3 & 64 & 9 & 239 & 1550 \\
\hline$\underline{1999}$ & ICTV 7th Report (MSL \#18) & 3 & 64 & 9 & 234 & 1551 \\
\hline$\underline{1998}$ & Postal vote autumn 1998 (MSL \#17) & 3 & 63 & 9 & 233 & 2370 \\
\hline 1997 & Postal vote autumn 1997 (MSL \#16) & 2 & 56 & 9 & 197 & 2267 \\
\hline$\underline{1996}$ & Plenary session vote August 1996 in Jerusalem (MSL \#15) & 2 & 53 & 9 & 182 & 2253 \\
\hline$\underline{1995}$ & ICTV 6th Report (MSL \#14) & 1 & 50 & 9 & 166 & 2220 \\
\hline$\underline{1993}$ & Plenary session vote 10 August 1993 in Glasgow (MSL \#13) & 1 & 49 & 9 & 160 & 1700 \\
\hline$\underline{1991}$ & ICTV 5th Report (MSL \#12) & 1 & 40 & 9 & 142 & 1674 \\
\hline$\underline{1990}$ & Plenary session vote 29 August 1990 in Berlin (MSL \#11) & 1 & 40 & 9 & 137 & 1290 \\
\hline$\underline{1987}$ & Plenary session vote 12 August 1987 in Edmonton (MSL \#10) & 0 & 37 & 8 & 116 & 1275 \\
\hline$\underline{1984}$ & Plenary session vote 5 September 1984 in Sendai (MSL \#09) & 0 & 35 & 8 & 103 & 1222 \\
\hline$\underline{1982}$ & ICTV 4th Report (MSL \#08) & 0 & 29 & 8 & 97 & 1209 \\
\hline$\underline{1981}$ & Plenary session vote 4 August 1981 in Strasbourg (MSL \#07) & 0 & 29 & 8 & 93 & 1091 \\
\hline$\underline{1979}$ & ICTV 3rd Report (MSL \#06) & 0 & 24 & 8 & 84 & 1008 \\
\hline$\underline{1978}$ & Plenary session vote 30 August 1978 in The Hague (MSL \#05) & 0 & 24 & 7 & 76 & 760 \\
\hline$\underline{1976}$ & ICTV 2nd Report (MSL \#04) & 0 & 17 & 3 & 67 & 754 \\
\hline$\underline{1975}$ & $\begin{array}{l}\text { Plenary session vote } 12 / 16 \text { September } 1975 \text { in Madrid (MSL } \\
\# 03)\end{array}$ & 0 & 17 & 1 & 63 & 309 \\
\hline$\underline{1974}$ & Postal vote April-May 1974 (MSL \#02) & 0 & 5 & 0 & 49 & 298 \\
\hline$\underline{1971}$ & ICTV I st Report (MSL \#01) & 0 & 2 & 0 & 43 & 290 \\
\hline
\end{tabular}

Fig. 3 Screen shot of the ICTV web site historical taxonomy releases, http://www.ictvonline.org/taxonomyReleases.asp

records (e.g. minutes recording the results of ICTV ballots) where available. As explained above, the recognition of new member viruses (or species) before 1996 can usually only be traced to the publication of a particular report. It is helpful to remember that while the taxonomic levels of orders, families, subfamilies, genera and species are recognised in virus taxonomy, not all these levels are necessarily used. Each species is a member of a higher taxon; this is usually a genus, but sometimes a species may be placed within a family or subfamily but not assigned to 


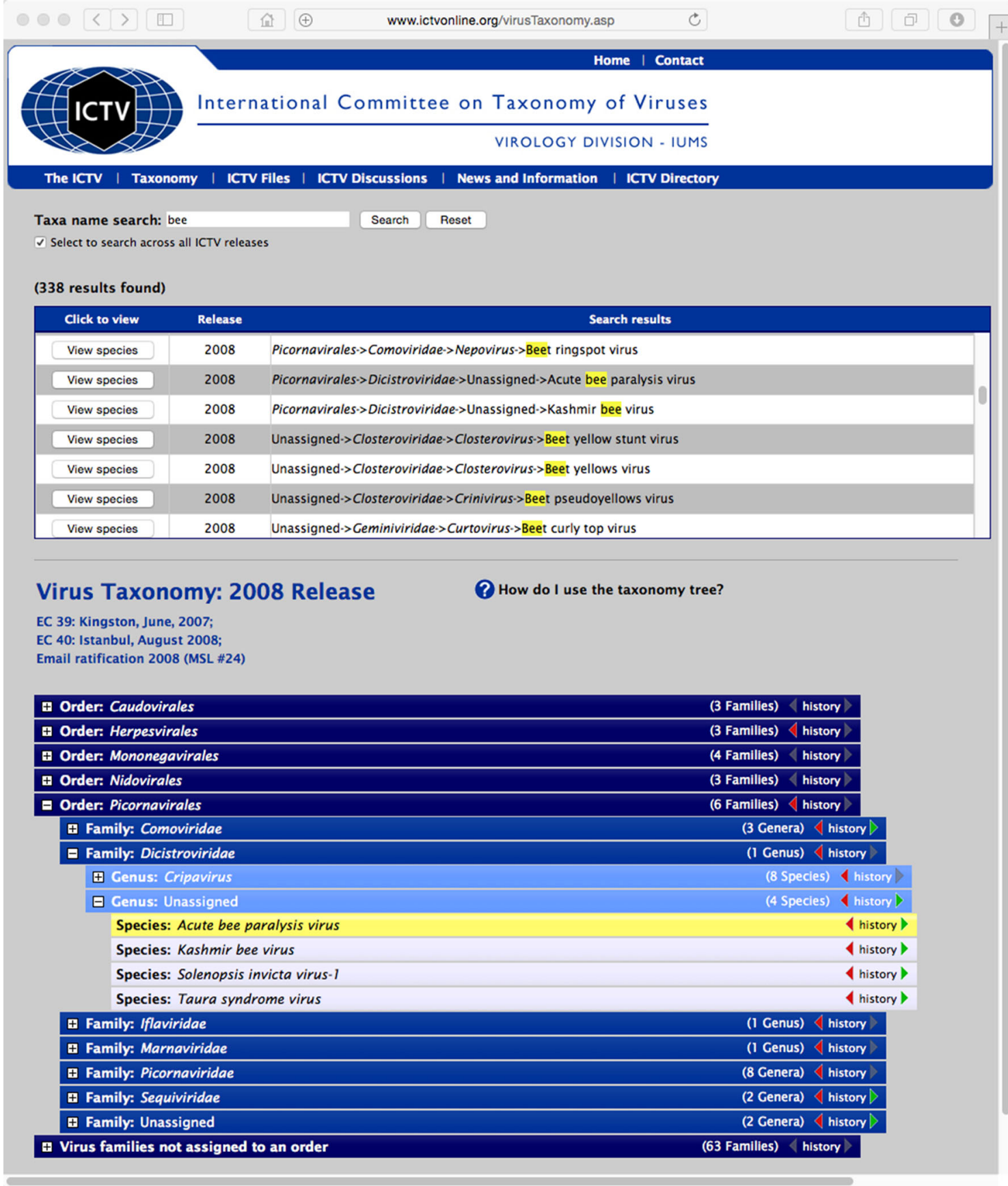

Fig. 4 Screen shot of the ICTV web site taxonomy search page

any current genus. Most genera, but not all, are placed in families. Many families are not currently assigned to an order, and few of them are divided into subfamilies.

\section{Using the web site}

The ICTV web site (Fig. 1, http://www.ictvonline.org) provides access to a wide variety of information pertinent to ICTV activities. This information includes copies of the ICTV Statutes and Code of Virus Classification ("The ICTV" menu); both approved and pending taxonomy proposals as well as downloadable copies of the complete virus taxonomy-the Master Species List ("ICTV Files" menu); and lists of Executive Committee, Subcommittee, and Study Group members ("ICTV Directory" menu). The current, and all past, releases of the virus taxonomy can be accessed from the ICTV taxonomic database and displayed 


\section{ICTV Taxonomy History for Acute bee paralysis virus}

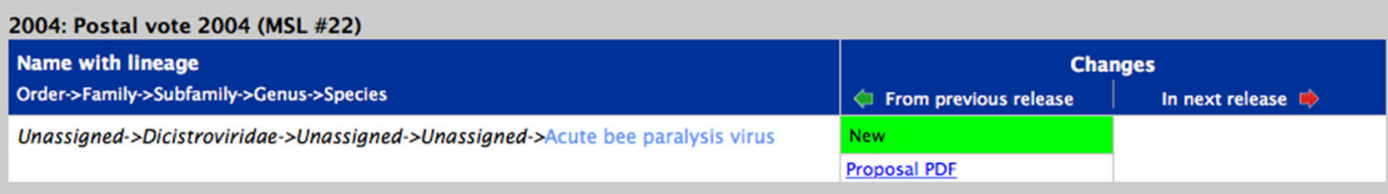

2005: ICTV 8th Report (MSL \#23)

\begin{tabular}{|c|c|c|}
\hline \multirow{2}{*}{$\begin{array}{l}\text { Name with lineage } \\
\text { Order }>\text { Family }>>\text { Subfamily }>\text { Cenus }>>\text { Species }\end{array}$} & \multicolumn{2}{|c|}{ Changes } \\
\hline & $\diamond$ From previous release & In next release $\Rightarrow$ \\
\hline Unassigned->Dicistroviridae->Unassigned->Unassigned->Acute bee paralysis virus & & Moved \\
\hline \multicolumn{3}{|l|}{$\begin{array}{l}\text { 2008: EC 39: Kingston, June, 2007; } \\
\text { EC 40: Istanbul, August 2008; } \\
\text { Email ratification } 2008 \text { (MSL \#24) }\end{array}$} \\
\hline \multirow{2}{*}{$\begin{array}{l}\text { Name with lineage } \\
\text { Order }>\text { Family }>\text { Subfamily }>>\text { Genus }>\text { Species }\end{array}$} & \multicolumn{2}{|c|}{ Changes } \\
\hline & $\measuredangle$ From previous release & In next release $\Rightarrow$ \\
\hline \multirow[t]{2}{*}{ Picornavirales $->$ Dicistroviridae $->$ Unassigned->Unassigned->Acute bee paralysis virus } & Moved & $\begin{array}{l}\text { Moved, } \\
\text { Assigned as Type Species }\end{array}$ \\
\hline & & Proposal PDF \\
\hline
\end{tabular}

2009: ICTV 9th Report;

EC41: Leiden, June 2009;

Email ratification 2009 (MSL \#25)

Name with lineage

Order $>$ Family $>>$ Subfamily $>>$ Genus $\rightarrow$ Species

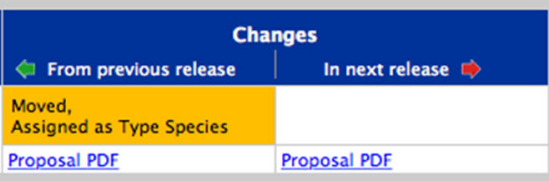

2011: EC 42: Paris, June, 2010;

EC43: Sapporo, September 2011;

Email ratification 2012 (MSL \#26)

Name with lineage
Order $>$ Family $\rightarrow$ Subfamily $\rightarrow>$ Genus $\rightarrow$ Species

Picornavirales->Dicistroviridae->Unassigned->Aparavirus->Acute bee paralysis virus

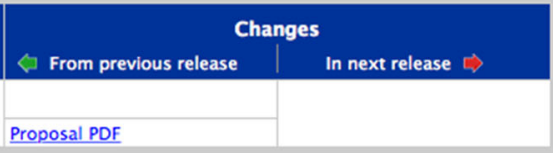

2012: EC 44, Leuven, July 2012;

Email ratification 2013 (MSL \#27)

Name with lineage

Order $>$ Family $>>$ Subfamily $>$ Genus $\rightarrow$ Species

Changes

Picornavirales->Dicistroviridae->Unassigned->Aparavirus->Acute bee paralysis virus

2013: EC 45, Edinburgh, July 2013;

Email ratification 2014 (MSL \#28)

Name with lineage

Order $>$ Family $\rightarrow$ Subfamily $\rightarrow$ Genus $\rightarrow$ Species

Changes

Picornavirales->Dicistroviridae->Unassigned->Aparavirus->Acute bee paralysis virus

Fig. 5 Screen shot of the ICTV web site taxon history web page

from web links provided by the "Taxonomy" menu. The current taxonomy release (Fig. 2, http://www.ictvonline. org/virusTaxonomy.asp) displays a list of the complete taxonomic hierarchy organized alphabetically according to taxonomic rank. Each rank displayed within this taxonomy tree can be expanded by clicking on the + sign to the left of the taxon name. A list of historical ICTV releases is also available (Fig. 3, http://www.ictvonline.org/taxonomyR eleases.asp). This list displays the year that the release was approved by the EC, the release number and location of the EC meeting during which the release was compiled, and statistics detailing the number of entries for each taxon rank. Clicking on the release year will open a web page that provides access to the corresponding taxon list. Release numbers are composed of up to three items: a MSL number that corresponds to the release number of the Master Species List, an EC number that corresponds to the Executive Committee meeting at which the proposals were 
Table 2 Terminology used to describe taxon changes

\begin{tabular}{|c|c|c|}
\hline Term & Description & Example \\
\hline New & Creation of a new taxon & $\begin{array}{l}\text { In } 2004 \text {, the species Acute bee paralysis virus was created in the family } \\
\text { Dicistroviridae }\end{array}$ \\
\hline Abolished & Removal of a taxon & In 2011, the species Hawaiian rubus leaf curl virus was abolished \\
\hline Renamed & Renamed taxon & In 2012, the species Bovine enterovirus was renamed Enterovirus E \\
\hline Moved & $\begin{array}{l}\text { Moving a taxon to a different higher-level } \\
\text { taxon }\end{array}$ & $\begin{array}{l}\text { In 2009, the species Acute bee paralysis virus was moved into the } \\
\text { genus Aparavirus }\end{array}$ \\
\hline Split & Splitting a taxon into two or more taxa & $\begin{array}{l}\text { In 1979, the species Bovine enterovirus was split into Bovine } \\
\text { enterovirus } 1 \text { and Bovine enterovirus } 2\end{array}$ \\
\hline Merged & $\begin{array}{l}\text { Merging two or more taxa into a single } \\
\text { taxon }\end{array}$ & $\begin{array}{l}\text { In } 1999 \text {, the species Bovine enterovirus } 1 \text { and Bovine enterovirus } \\
2 \text { were merged into a single species, Bovine enterovirus }\end{array}$ \\
\hline Assigned as Type Species & $\begin{array}{l}\text { Assigning a species as the type species of } \\
\text { the genus }\end{array}$ & $\begin{array}{l}\text { In 2009, the species Acute bee paralysis virus was assigned as the } \\
\text { type species of the genus Aparavirus }\end{array}$ \\
\hline Removed as Type Species & $\begin{array}{l}\text { Removing a species as the type species of } \\
\text { the genus }\end{array}$ & $\begin{array}{l}\text { In } 2005 \text {, the species Poliovirus was removed as the type species } \\
\text { of the genus Enterovirus }\end{array}$ \\
\hline
\end{tabular}

Fig. 6 Graph showing changes to the numbers of genera, families, subfamilies and orders recognised by the ICTV, 1971-2014

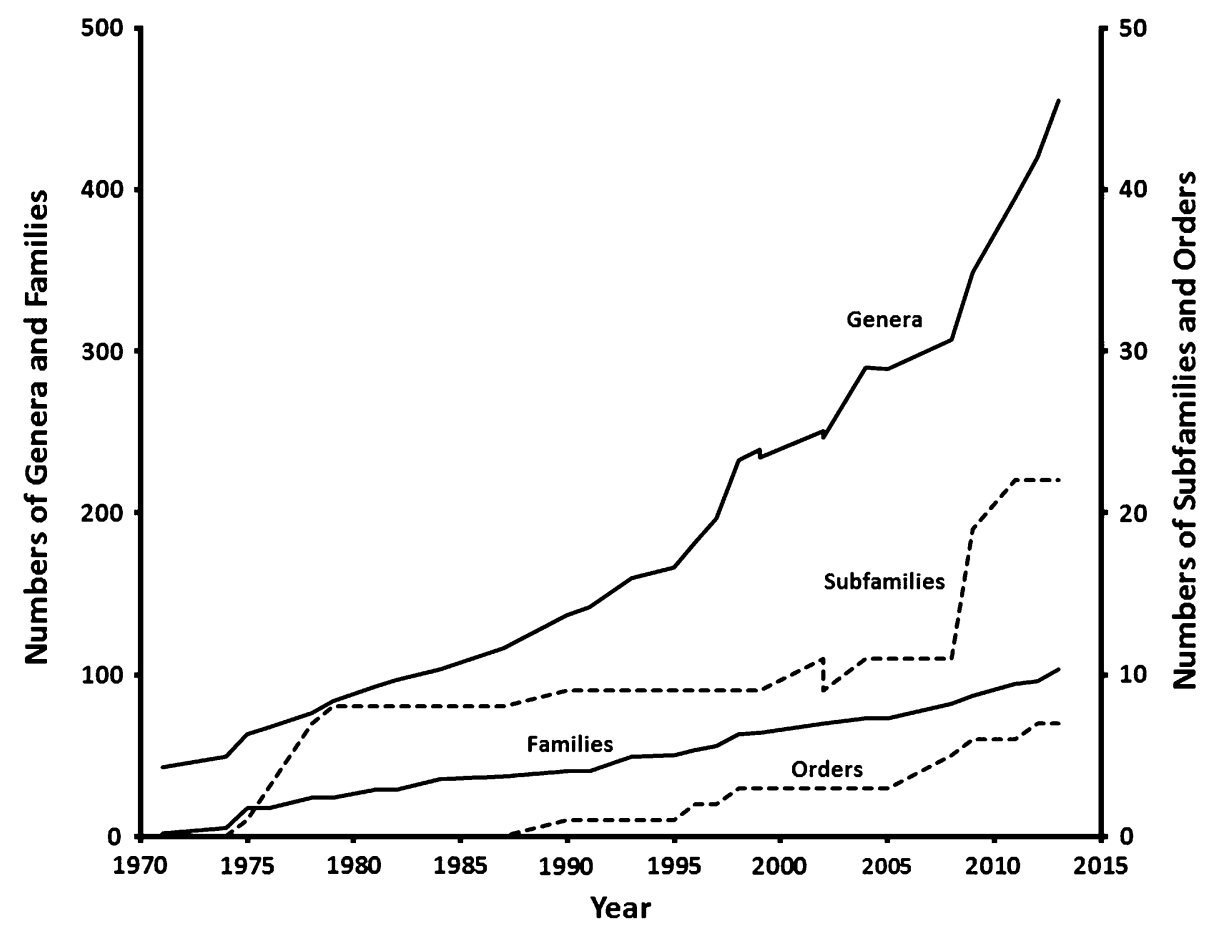

discussed and approved, and an ICTV Report number that corresponds to the volume number of the ICTV Report's publication for that MSL release.

To search for a particular taxon across all taxonomy releases, a taxon name (or partial name) can be entered into the search box at the top of any taxonomy release page (Fig. 4). For example, entering the search term "bee" will result in a list of all taxon names that include the characters "bee" as a part of the name. The result set provides a list of these taxa, along with the year of each release in which each taxon name appears. Clicking on the "View" button to the left of the taxon will expand the taxonomy tree for that particular release, and highlight the taxon name in yellow (Fig. 4). To the right of each taxon name is a "history" link. A left and right arrow brackets the history link. If these arrows are colored, this provides an indication that the taxon has been updated from the previous release (red left arrow) and/or was updated in the next release (green right arrow). The "history" link opens a web page that provides the complete history of the taxon (Fig. 5) that 
summarizes all of the changes to the taxon over the years during which that taxon has existed. The terminology used to describe changes to a taxon's history is provided in Table 2.

\section{Conclusions}

Compilation of these data has provided a thorough check of the ICTV records. A small number of mistakes, mostly in the spelling of species names, that became incorporated into Reports have been identified and corrected. Such corrections have been the subject of formal proposals to maintain comprehensive records. With very few exceptions, all taxonomic changes involving genera or higher taxa have been traced to published records. Procedures for presenting, reviewing and approving taxonomic proposals have developed over time but have become increasingly detailed and transparent in the last 10-15 years. The proposals of the last 10 years have all been assembled and linked to the database, providing a detailed justification for the changes made. Since 1971, the numbers of genera have risen from 43 to 455 and families from 2 to 103 (Fig. 6). This reflects a huge amount of work in virus discovery and characterization as well as the effort involved in making and evaluating taxonomic proposals. The speed of change will likely increase in the years ahead, and it is intended that this database will provide an ongoing and updated record of those changes.

Acknowledgments We thank past and present members of the Executive Committee of ICTV for their interest. We particularly thank Drs L. A. Ball, E. B. Carstens, A. M. Q. King and H. J. Vetten for their enthusiastic help in tracing ICTV documents included in this project and Dr. A. E. Gorbalenya for constructive suggestions.

\section{References}

1. Adams MJ, Carstens EB (2012) Ratification vote on taxonomic proposals to the International Committee on Taxonomy of Viruses (2012). Arch Virol 157:1411-1422

2. Adams MJ, Lefkowitz EJ, King AMQ, Carstens EB (2014) Ratification vote on taxonomic proposals to the International Committee on Taxonomy of Viruses (2014). Arch Virol 159:2831-2841

3. Adams MJ, King AMQ, Carstens EB (2013) Ratification vote on taxonomic proposals to the International Committee on Taxonomy of Viruses (2013). Arch Virol 158:2023-2030

4. Carstens EB (2010) Ratification vote on taxonomic proposals to the International Committee on Taxonomy of Viruses (2009). Arch Virol 155:133-146

5. Carstens EB, Ball LA (2009) Ratification vote on taxonomic proposals to the International Committee on Taxonomy of Viruses (2008). Arch Virol 154:1181-1188
6. Fauquet C, Mayo MA, Maniloff J, Desselberger U, Ball LA (eds) (2005) Virus taxonomy: eighth report of the International Committee on Taxonomy of Viruses. Elsevier, Amsterdam

7. Fenner F (1976) Classification and nomenclature of viruses. Second report of the International Committee on Taxonomy of Viruses. Intervirology 7:1-115

8. Fenner F, Pereira HG, Porterfield JS, Joklik WK, Downie AW (1974) Family and generic names for viruses approved by the International Committee on Taxonomy of Viruses, June 1974. Intervirology 3:193-198

9. Francki RIB, Fauquet CM, Knudson DL, Brown F (1991) Classification and nomenclature of viruses. Fifth report of the International Committee on Taxonomy of Viruses Archives of Virology. Arch Virol Suppl 2. Springer, Wein

10. King AMQ, Adams MJ, Carstens EB, Lefkowitz EJ (eds) (2011) Virus taxonomy, ninth report of the International Committee on Taxonomy of Viruses. Elsevier Academic Press, London

11. Matthews REF (1979) Classification and nomenclature of viruses. Third report of the International Committee on Taxonomy of Viruses. Intervirology 12:129-296

12. Matthews REF (1982) Classification and nomenclature of viruses. Fourth report of the international committee on taxonomy of viruses. Intervirology 17:1-199

13. Mayo MA (2002) Virus taxonomy-Houston 2002. Arch Virol 147:1071-1076

14. Mayo MA (2002) A summary of taxonomic changes recently approved by ICTV. Arch Virol 147:1655-1656

15. Mayo MA (2002) ICTV at the Paris ICV: results of the plenary session and the binomial ballot. Arch Virol 147:2254-2260

16. Mayo MA (2005) Changes to virus taxonomy 2004. Arch Virol 150:189-198

17. Murphy FA, Fauquet CM, Bishop DHL, Ghabrial SA, Jarvis AW, Martelli GP, Mayo MA, Summers MD (1995) Virus taxonomy. Sixth report of the International Committee on Taxonomy of Viruses. Springer, Wien

18. Pringle CR (1993) Virus taxonomy update. Taxonomic decisions ratified at the plenary meeting of the ICTV at the 9th international congress of virology held in Glasgow on the 10th August 1993. Arch Virol 133:491-495

19. Pringle CR (1996) Virus taxonomy 1996-a bulletin from the Xth international congress of virology in Jerusalem. Arch Virol 141:2251-2256

20. Pringle CR (1997) Virus taxonomy-1997. In: Proceedings of the 26th Meeting of the Executive Committee of the ICTV, Strasbourg, France, May 10-11, 1997. Arch Virol 142:1727-1733

21. Pringle CR (1998) Virus taxonomy-San Diego 1998. Arch Virol 143:1449-1459

22. Pringle CR (1999) Virus taxonomy at the XIth International Congress of Virology, Sydney, Australia, 1999. Arch Virol 144:2065-2070

23. Pringle CR, Fauquet CM (1998) ICTV announcement-ratification of new taxonomic proposals. Arch Virol 143:2504

24. van Regenmortel MHV, Fauquet CM, Bishop DHL, Carsten EB, Estes MK, Lemon SM, Maniloff J, Mayo MA, McGeoch DJ, Pringle CR, Wickner RB (2000) Virus taxonomy. Seventh report of the International Committee on Taxonomy of Viruses. Academic Press, San Diego

25. Wildy P (1971) Classification and nomenclature of viruses. First report of the International Committee on Nomenclature of Viruses. Monog Virol 5:1-81 